\title{
Effect of Supplementation on the Properties of Yogurt: A Review
}

\author{
S. B. Kumthekar*, S. S. Temgire, A. B. Idate and V. R. Gaikwad \\ Department of Food Science and Nutrition, School of Agriculture, Lovely Professional \\ University, Jalandhar, Punjab, India \\ *Corresponding author
}

\section{A B S T R A C T}

Keywords

good source of protein, calcium, phosphorus, thiamine, riboflavin

Article Info

Accepted:

12 March 2021

Available Online:

10 April 2021
Yogurt is a fermented probiotic milk drink produced by the action of bacteria which break down the complex compounds in the milk to produce more nutritious acidic product. Yogurt is famous worldwide due its characteristic flavour and taste. It is well known that it has potential to promote the health by improving the gut microflora, curing many diseases like diarrhea, intestinal disorder, type 2 diabetes and cardiovascular disorders. Yogurt itself highly reaches in protein, calcium, phosphorous, thiamine, folate, riboflavin, vitamin B12, niacin, zinc and magnesium. Considering the present trend, production of fortified food with high nutrients is essential. Yogurt has high popularity due to its versatile nature mainly amongst women, children and elder people hence; yogurt with essential nutrients can reduce the deficiency in the diet. At present many researches focused on the production of reduced fat fortified yogurt with minimum change in the sensory as well as physicochemical properties. The fortifying agents can have a chemical interaction with active compounds in the yogurt. In this review, the effects of milk fortification with various food components on physicochemical as well on sensorial properties of yogurt products are studied and described. The fortification described under the types of food components like carbohydrates, proteins, dietary fibres, minerals and vitamins.

\section{Introduction}

Nowadays fermentation process became very popular technique because fermented foods have extended shelf life and has high nutrients. The method of fermentation has been in use from thousands of years. Today many foods like fruits, vegetables, meat, fish, cereals and milk have all been processed by fermentation and converted into more simpler and beneficial product by using enzymes. Fermentation is a chemical process in which enzymes brake down organic compound into simpler form which is easy to digest. Certain microbes like bacteria's which is part or product of fermentation reported to have high health benefits (Yousef and Carlstrom, 2003).

Fermented milk products from different animals are most popular fermented foods 
worldwide in which yogurt is more common in different countries. It is known by various names everywhere. It produced and consumed massively in most of the countries. Yogurt is a fermented dairy product produced by the action of Streptococcus thermophilus and Lactobacillus delbrueckii spp. Bulgaricus. The origin of fermented milk product i.e. Yogurt is Middle East and it spreads all over the world. Yogurt is more nutritious compared to milk and it is a good source of protein, calcium, phosphorus, thiamine, riboflavin, folate, vitamin B12, niacin, zinc and magnesium. The lactose in the milk is fermented to lactic acid by Lactic Acid Bacteria (LAB) and hence lactose intolerant peoples can consume the yogurt without any health concerns. Addition to it, consumption of yogurt instead of milk lowers the $\mathrm{pH}$ of stomach resulting into reduction of transit of pathogen. Yogurt also can be used to provide heart healthy nutrients in the diet (O'connell and Fox, 2001).

Yogurt can be consumed either as a dessert or as a snack. It has high popularity mainly among the children, women and teenagers who eat yogurt daily in the diet (Hekmat and Macmahon, 1997). The steady increase in the consumption of yogurt is been reported in the United States over the last 30 years (USDA, 2002).

Yogurt has plenty of known health advantages and the intense studied have been conducted on the benefits to the health from fermented milk drinks. From ancient time's fermented products from milk recognised as enhancer of intestinal health. Fermented milk drinks used to cure the diarrhea and other intestinal disorders even before the scientific researches approved it. The starter culture of yogurt carries S. thermophilus and L. delbrueckii ssp. Bulgaricus which are considered as probiotic strains. To improve the gut microflora and metabolic activities in the stomach yogurt is more than helpful. Microbial balance in the gut is important to keep away the gastrointestinal disorders. The bacteriocins and hydrogen peroxide produced by the yogurt bacteria is an antimicrobial agent which retard the growth of pathogenic bacteria. Apart from it, yogurt is produced from the milk which is highly reached in several nutrients which further increased by the metabolic activity of yogurt culture. Milk contains easily available phosphorus, calcium, magnesium and protein which are must for strong bones and healthy development and growth in children (Chandan et al., 2017). The calcium and magnesium content in the yogurt can reduce the risk of type 2 diabetes. Additionally, yogurt can also be beneficial in the prevention of cardiovascular disorder (Astrup, 2014; Marette and Pickard-Deland, 2014).

The industrial production process of yogurt consists of different processing steps which changes the milk into non reversible way. In the beginning, the fat content and solid not fat (SNF) content is standardized to desired level by addition or removal of cream or skim milk powder (Lee and Lucey, 2010). To improve nutritional and functional properties and to prevent textural defects fortification of milk can be done(Dave and Shah, 1998; Schkoda et al., 2001; Séverin and Wenshui, 2005; Marafon et al., 2011). Fortification of milk then followed by homogenization at 10-20 $\mathrm{MPa}$ at first stage and $5 \mathrm{MPa}$ at second stage in the temperature range of $55-65^{\circ} \mathrm{C}$. This process increases amount of possible structure binding components in yogurt by generating fat globules with new surface layer formed by the caseins and whey proteins. Then milk is exposed to heat treatment at $85^{\circ} \mathrm{C}$ for $30 \mathrm{~min}$ or at $90-95^{\circ} \mathrm{C}$ for $5-10 \mathrm{~min}$ or at $115^{\circ} \mathrm{C}$ for $3 \mathrm{sec}$. Heat treatment of milk resulting into protein denaturation which initiates the gelation process. Afterwards, cooling of milk is done to temperature of $40-45^{\circ} \mathrm{C}$ which is considered as inoculation temperature. Subsequently, the inoculation of 
Streptococcus thermophilus and Lactobacillus delbrueckii spp. bulgaricus (Tamime \& Robinson, 2000; Damin et al., 2009; Peng et al., 2009) is performed which produces lactic acid by converting lactose. A minimum of 10 million live microorganisms should be in per gram of yogurt at the time of consumption is defined by the AFNOR standards. In the fermentation process, Lactobacilli proteolytic activity stimulates growth of Strep. thermophilus, formic acid and $\mathrm{CO} 2$ released by Lb. Bulgaricus. The count of microorganism Strep. thermophilusis higher than Lb. Bulgaricus at the final stage. In the end flavouring agents, fruits, stabilizers and thickeners are mixed before chilling and cold storage. Yogurt manufacturing and quality primarily depends on the proportion and nature of the milk proteins. Yogurt mixture composition, buffering capacity, protein interaction, and fermentation time, textural and sensorial properties improves by the method of enrichment (Kristo et al., 2003; Soukoulis et al., 2007; Lee and Lucey, 2010).

Considering present trend consumers are more health conscious and prone to fortified food with essential nutrients. Fortification of food with natural sources is a great way to increase the overall nutrient content of food with minimizing side effects is reported by many nutrition scientists (Nestle, 2013). Till date numerous studies and researches are conducted regarding the fortification of yogurt (Gahruie et al., 2015; Gupta et al., 2015; Karam et al., 2013; Ocak and Köse, 2010). Fortification of yogurt can induce the chemical reaction and have an impact on the quality and physicochemical properties of yogurt like rheological behaviour, structure, flavour and sometimes odd flavour. Hence, to find alternatives is paramount to reduce the potentially unwanted effects while maximizing the benefits of fortification on the quality of yogurt (Mehar-Afroz et al., 2012; Sharifi et al., 2013).
In this review, the main focus is to cover the effects of milk fortification with various food components like proteins, carbohydrates, minerals, vitamins and dietary fibres on physicochemical as well on sensorial properties of yogurt products are studied and described.

\section{Supplementation with Carbohydrates}

Carbohydrates is an important biomolecule which includes complex structure of Carbon $(\mathrm{C})$, Hydrogen $(\mathrm{H})$ and Oxygen $(\mathrm{O})$ in which the ratio of hydrogen and water molecules is 2:1 like water. It will further classified into monosaccharide, oligosaccharide and polysaccharide based on no. of carbon-carbon chains. Sugars, starch and cellulose are some forms of carbohydrates. Many researchers tried to incorporate different forms of carbohydrates into the yogurt i.e. fructose, sucrose (Fernandez-Garcia et al., 1998; Haque and Aryana, 2002), native maize starch, chemically modified maize starch, tapioca starch (Lobato-Calleros et al., 2014), pectin and pectic oligosaccharide (Sabater et al., 2020), potato starch, maize starch, waxy maize starch (Najgebauer-Lejko et al., 2007), modified cassava starch (Imbachi-narvaez et al., 2018), Carboxy Methyl Cellulose, Canna Edulis Ker Starch (Umam et al., 2018), caramel jam (Ramirez-Sucre and Velez-Ruiz, 2013), galactomannans gaur and locust bean gum (Kok, 2010), lentil flour (Zare et al., 2012), monk fruit extract (Ban et al., 2020) and studied the effect of it on the physical as well as chemical properties of yogurt.

\section{Effect on the pH and acidity of yogurt}

Acidity and $\mathrm{pH}$ of is an important property of yogurt resulting of lactose fermentation which converts lactose into lactic acid by the associative growth of thermophilic and homofermentative lactic acid bacteria i.e. S. thermophilus and Lactobacillus delbrueckii 
ssp. Bulgaricus which reduces the $\mathrm{pH}$ up to level of 4.5. Acidity and $\mathrm{pH}$ is generally used to determine the success of fermentation process. Primarily, lactic acid has a major role in defining the $\mathrm{pH}$ and acidity where, acetic acid is also present in yogurt (Sabater et al., 2020). Any change in the desired $\mathrm{pH}$ level tends to discoloration, excess of insufficient tartness of yogurt and excessive free whey. The $\mathrm{pH}$ of the yogurt is dependent on the storage time as it decreases with increase in the storage time. Generally, the addition of carbohydrates into the yogurt leads to change in $\mathrm{pH}$ to some extent. Incorporation of polysaccharides majorly starches into the yogurt are able to increase the acidity of the yogurt drastically compared to plain yogurt. The increase in acidity is due to excessive growth and survival of probiotic bacteria results into rapid conversion of lactose into lactic acid (Lobato-Callerosa et al., 2014).

Different forms of carbohydrates can have different effects on the $\mathrm{pH}$ and acidity of yogurt. Carbohydrates like Fructose (Fernandez-Garcia and Mcgregor, 1998), Canna starch (Umam et al., 2018) and Caramel jam (Ramírez-Sucre and Vélez-Ruiz, 2013)increases the $\mathrm{pH}$ and decrease the acidity of yogurt drink whereas, opposite results obtained by the sago starch (Umam et al., 2018) and lentil flour (Zare et al., 2012) incorporation. The increase in the $\mathrm{pH}$ may be due to the antibacterial effect of some carbohydrates and decrease in $\mathrm{pH}$ might be the result of lower buffering capacity of them. Apparently, few carbohydrates like modified cassava starch (Imbachi-Narvaez et al., 2018), galactomannans guar and locust bean gum (Kok, 2010) not able to alter the $\mathrm{pH}$ and acidity due to good buffering capacity. Increased $\mathrm{pH}$ of yogurt drink leads to excessive fermentation time as decreased $\mathrm{pH}$ value lowered the time required for fermentation(Fernandez-Garcia and Mcgregor, 1998).

\section{Effect on the degree of syneresis}

Syneresis referred as important property of yogurt which related to the presence of liquid on the yogurt gel surface. The liquid is a resulting of shrinkage in fermentation process and responsible for whey loss. The syneresis changes the consumer's approach towards the yogurt as higher syneresis percentage considered as defect in yogurt type products. Many reasons like formulation of milk, low solids, decrease in $\mathrm{pH}$, excessive acidity, increase in incubation temperature, protein denaturation, variations in storage temperature, etc. had an impact on the syneresis formation in yogurt (Amaya-Llano et al., 2008; Sah et al., 2016).

Researchers used stabilizers to reduce the syneresis percentage in yogurt. Different types of starches i.e. modified or without modification used as stabilizers to reduce the degree of syneresis. All types of sugars and starches decrease the syneresis formation of yogurt except monk fruit extract (Ban et al., 2020) as it has no effects on the syneresis production. Decrease in the syneresis is may be either by increased total solids or by high water binding capacity of sugar and starches. The ability of retrogradation of starches also had a roll in reduction of syneresis (ImbachiNarvaez et al., 2018).

Substantial amount of water is retained by the starches into weak gel structure which can be useful in achieving fat mimetic properties of yogurt. Banana starch (Han et al., 2005) has better water holding capacity compared to other native starches like corn and rice starch (Lobato-Calleros et al., 2014) because of presence of hydrophilic groups. Unmodified starches have less water binding capacity than hydroxypropylated waxy rice and corn starch which results into elevation in syneresis production (Han et al., 2005; Lobato-Calleros et al., 2014). 


\section{Effect on the rheological property of yogurt}

Viscosity is the major factor in the retardation from settling and the aggregation of solids suspended in drinks. Yogurt is known to be non-thixotropic fluid in nature due to the irreversible breakable structure using shear stress. Yogurt displayed shear thinning behaviour. It has both pseudoplastic and thixotropy behaviour because of increase in shear stress observed with increase in the shear thinning. Sometimes time dependant change in viscosity and decrease in the viscosity with constant shear rate is observed in yogurt considered as thixotropy behaviour and it shows by pseudoplastic fluids. The change in viscosity and flow behaviour of yogurt may be due to variation in heat treatment, bacterial strain and incubation temperature (Kok, 2010). The viscosity of the yogurt incorporated with different carbohydrates is shown in the Table.

Increase in the total solid content of milk responsible for increase in the viscosity of yogurt, hence addition of starches and sugars in the milk tend to increase the apparent viscosity of yogurt. The interaction between the modified starches and casein micelles has provided firm gel structure to the yogurt which increases the viscosity. When the carbohydrate incorporated yogurt kept for longer storage the viscosity tend to decrease because of post acidification action of bacterial strains. Propensity of the yogurt to expel water is increases after the storage; it might be the reason of the loss in the apparent viscosity of the yogurt incorporated with starches because the water can play a role of lubricant between the fat globules and casein chain. During the swelling of starch while absorbing the water from continuous phase it increases the concentration of milk protein. Added starch formed composites with protein which decreases the syneresis index and increase the resulting viscosity. Amylopectin has high water holding capacity which decreases the syneresis and results into increase in the viscosity of yogurt. Similarly, whey protein concentrate develop an interpenetrating continuous network which enhances the water holding capacity (LobatoCallerosa et al., 2014). The incorporation of canna starch into the yogurt improved the viscosity; it may be due to pectin concentration in canna flour (Umam et al., 2018). Addition of fructose in the milk or by using lactose hydrolysed milk before fermentation increases the viscosity of the final yogurt, it was due to the increased soluble solid content and sugars has great water binding capacity (Fernandez-Garcia and Mcgregor, 1998).

\section{Effect on the sensory of yogurt}

Along with taste other sensory attributes like flavour, appearance, texture and mouth feel are important properties regarding yogurt that it cannot be marketable if the taste and other visual characteristics are not satisfied the consumers. Beside the fortification, Yogurt must taste delicious with retaining its original flavour. The taste of the yogurt added with sugars improved but with moderate use it's preferable as consumers liked it with average sweet taste. Sucrose and fructose are likely to be added for sweetening the yogurt as the quantity of glucose and galactose released by the hydrolysis of lactose present in yogurt is not enough to give it required sweetness. When the flavour is considered the acetaldehyde is a prime contributor and it got affected with addition of sugars in yogurt. The overall acetaldehyde flavour lowered with increase in storage time with the addition of sugars. The texture and mouth feel of the yogurt increases with addition of sugars where sucrose improved it drastically compared with fructose (Fernandez-Garcia and Mcgregor, 1998). Potato starch (Najgebauer-Lejko et al., 2007) and canna starch (Umam et al., 2018) 
does not affect the sweetness, color, acidic flavour, sourness, thickness, smoothness and overall acceptability. Modified starches stabilize the structure of yogurt as starches reinforce the structure through casein starch interaction. Galactomannans gum (Kok, 2010) above the concentration of $0.5 \%$ has difficulties in swallowing and adversely affects the mouth feel of the yogurt. Hydrocolloid incorporation does give the oily mouth feel to the yogurt above the $0.25 \%$ concentrations but, does not affect the taste and odour. The excess use of stabilizer has negative impact on the mouth feel and flavour (Kok, 2010). Colour of the yogurt always had an impact on the consumer's perception when buying, and it affected by the fortification with carbohydrates. The colour gives hint about the storage time and shelf life depending on the colour deterioration. Pomegranate juice powder reduces the whiteness of the yogurt but with increasing the storage time it did not affect the whiteness considerably. The reduced effect of pomegranate juice powder on the whiteness of yogurt with storage time is due to solid matrix compaction (Pan et al., 2019).

\section{Supplementation with Proteins}

Proteins are substances important in all living organisms for its great nutrition's. It is highly complex in structure in which amino acid chains are linked with the peptide bonds. To provide highest satiating ability to different foods is an important property of protein molecule. Yogurt is also a protein based food product hence, it can be excellent basis to design fortified food from yogurt. Incorporation of different proteins can affect the typical structural arrangement of the whey or casein protein in the network of yogurt protein. These structural arrangements are closely connected to yogurts texture sensory evocation of various expectations of satiating ability. Many scientists have reported numerous researches in which different protein concentrates i.e. whey protein concentrate (Sodini et al., 2005; Needs et al., 2000), calcium caseinate, blend of whey protein concentrate with calcium caseinate (Morell et al., 2015), casein (Isleten and Karagu-Yuceer, 2008), soy protein (Drake et al., 2000), sodium caseinate, micellar casein (Peng et al., 2009), sodium calcium caseinate (Akalin et al., 2012), micro-particulated whey protein (Hossain et al., 2020), oil seed proteins like soy protein isolate and peanut flour (Schmidt et al., 1980) are added or replaced the milk powders or milk fat and have effect on the physical and textural properties of yogurt..

\section{Effect of added proteins on the $\mathrm{pH}$ and acidity}

Proteins and $\mathrm{pH}$ have important relation between them as the lowered $\mathrm{pH}$ with heat denatured the protein faster and $\mathrm{pH}$ of 4.6 and lower cause gel formation in yogurt. Yogurt fortified with whey protein does slow the fermentation process with slow decrease in $\mathrm{pH}$, and it is because of high ionic strength of yogurt added with whey protein (Isleten and Karagu-Yuceer, 2008). Variation in the buffering capacity of different proteins is responsible for the change in the $\mathrm{pH}$ of yogurt. Micellar casein and calcium phosphate have high buffering capacity compared to other proteins; hence the variation in the final $\mathrm{pH}$ is less in the yogurt fortified with such proteins. Highest buffering capacity was observed at $\mathrm{pH}$ of 5 in this type of yogurt. Other proteins are also have some kind of buffering activity which increases the total fermentation time required to reach desired $\mathrm{pH}$ of 4.6 (Peng et al., 2009).

The soy protein (Drake et al., 2000) based yogurt also shows similar kind of behaviour may be due to low essential nutrient available for lactic acid bacteria. The addition of soy protein below $5 \%$ does not able to affect the 
acidity and fermentation time of yogurt. The $\mathrm{pH}$ and acidity change is heavily affected by the storage time and temperature as the result of post fermentation activity of lactic acid bacteria. The yogurt incorporated with whey proteins or sodium calcium caseinate has tendency to lower the $\mathrm{pH}$ compared to other proteins due to increase in the amount of lactic acid produced during the fermentation by utilizing added nutrients (Akalin et al., 2012).

\section{Effect on the syneresis}

The overall consumer acceptability is highly affected by the syneresis as visibly it shows the defect that something happened to the yogurt. Proteins can affect the amount of syneresis produced during the fermentation and storage. All proteins are able to decrease the syneresis as they have high water holding capacity compared to skim milk powder. Whey protein concentrate can lower the syneresis more than any other proteins at the processing and also in the storage. The production of syneresis is depending on the ratio of casein to whey protein. As the ratio of casein to whey protein decreases, increase in the compactness of the microstructure of yogurt observed.

The increased compactness of the yogurt microstructure might lead to the high level immobilization of free water (Morell et al., 2015). Casein to whey protein ratio when lowered from 4:1 to 1:1 the syneresis of whey protein and skim milk powder fortified yogurt is reduced. At the ratio of $1: 1$ of casein to whey protein concentrate no syneresis will form while processing as well as in storage. Water binding capacity of yogurt is closely related to the ratio of casein to whey protein concentrate and as the increased ratio will improve the water binding capacity. The property of whey protein of higher solvation of micellar system and to form more branched network tend to decrease the susceptibility of losing the water when proposed to centrifugal force. Water holding capacity of the sodium calcium caseinate and blend of sodium calcium caseinate and whey protein does not change during the storage period. The yogurt added with whey protein tends to lose the water more compared to sodium calcium caseinate due to weak bond between water molecule and whey protein. The decrease in the $\mathrm{pH}$ at the end of the storage can stimulate the loosening of water in the yogurt fortified with whey protein concentrate (Akalin et al., 2012).

\section{Effect on the rheological property}

The amount of proteins and degree of denaturation of them is the key factor in controlling the rheological property of yogurt. The heat treatment given prior to inoculation also dictates the rheology as it affects the denaturation of the protein added or initially presents in the yogurt. Lower viscosity of yogurt is also might be the result of ropy starter culture even with high protein content. The water holding capacity is increases with increased protein content with resulted into low syneresis and further improve the viscosity as well. It is due to higher cross linkage in the network of yogurt and it elevated more by whey protein compared to other proteins. Whey protein denaturation in the presence casein gives more homogenous and close structure to the yogurt compared with addition of casein prior to the denaturation of whey protein and it is due to pre-denatured whey protein produce protein aggregates which are large in size and not able to form a coat around casein micelles (Sodini et al., 2005). The hardness of the yogurt sample fortified with whey protein remains constant during the storage even with the elevation in viscosity (Isleten and KaraguYuceer, 2008). Similar kind of behaviour was observed with the addition of Soy protein and sodium caseinate (Drake et al., 2000). The 
change in the viscosity with different proteins is may be due to interaction between the minerals present in the milk and proteins. The micellar state of casein can alter the rheological property of resulted yogurt (Peng et al., 2009). Sodium calcium caseinate and casein based proteins like sodium caseinate have advantage over the whey protein concentrate in improving the rheological properties of the final yogurt (Akalin et al., 2012).

\section{Effect on sensory}

The texture and palatability of the yogurt is dependent on the water binding and water holding capacity of the yogurt. The positive correlation between the milk protein concentrations and sensory characteristics is observed in the studies. Consequently, some undesirable changes also may happen with increase in the protein concentration (Morell et al., 2015). The flavour of the yogurt is dependent on the production of acetaldehyde during the fermentation. Fortification of proteins below $1 \%$ cannot affect the acetaldehyde production in the yogurt as acetaldehyde content only affected by the storage time and bacterial strain. It decreases with increase in the storage time. Some studies found that very slight reduction in the acetaldehyde content observed with caseinate enriched yogurt at high level (Isleten and Karagu-Yuceer, 2008). Soy proteins are also not able to alter the sensory acidity but it does affect the flavour and can produce beany or like off-flavour. Lower concentration of soy protein likely to keep the aroma of fermented dairy products but it decreases as the soy proteins concentration increases (Drake et al., 2000). Different proteins have different effect on the colour of the yogurt but in general most of the dairy proteins do not able to alter the colour. Soy protein does affect the colour with increase in yellowness and decreases lightness and redness (Akalin et al., 2012).

\section{Supplementation with Dietary Fibres}

Dietary fibres (DF) are the parts of food derived from the plant origin which cannot be digested or broken down in the human digestive system. A survey by American heart association reported that US resident has daily intake of only 15 grams of dietary fibres in their diet. Milk and milk products are generally deficient in dietary fibre so supplementation of dietary fibres into milk based products worth sense. Many researchers focused on incorporation of fibres like oat fibre (Fernandez-Garcia et al., 1998), inulin, pea, oat and wheat fibre (Dabija et al., 2018), carrot fibre (Venica et al., 2020), pineapple pomace fibre (Sah et al., 2016), glucagel (Repin et al., 2012), pumpkin fibre (Bakirci et al., 2016), apple pomace fibre (Jovanovic et al., 2020) and orange fibre (Kieserling et al., 2019; Sendra et al., 2010)in yogurt and they achieved the daily needs of fibre intake through the popular fermented milk products. High fibre yogurts are healthy and can play role in reducing diabetes, obesity, cancer, gastrointestinal disorder, hypercholesterolemia, constipation, ulcerative colitis, hypertension and hyperlipidemia. Consequently, it can improve the gastrointestinal immunity and intestinal microflora (Tomic et al., 2017; Sah et al., 2016; Dhingra et al., 2012; Hoppert et al., 2013; Ramirez-Santiago et al., 2010).

\section{Effect of dietary fiber incorporation on the pH and acidity}

Different dietary fibers can differently affect the $\mathrm{pH}$ and acids produced during the fermentation. The acidification rate is one the most important factor in the yogurt production as it is essential in the formation of the gel and to achieve desired commercial transportation time. Rate of acidification is one of the important detriments of yogurt making as it is important to achieve a balance between 
strength of the gel as well as commercially feasible fermentation time. It does affect the fermentation time to reach the desired $\mathrm{pH}$ of 4.5. The change in the $\mathrm{pH}$ also has effect of storage time on it. Oat fibers generally elevate the $\mathrm{pH}$ of yogurt compared to yogurt without addition of fibers (Fernandez-Garcia et al., 1998). Different observations are noticed regarding the effect of oat fibre on the $\mathrm{pH}$ of yogurt as Dabija et al., (2018) found no additional effect on the $\mathrm{pH}$ and acidity of yogurt.

Dabija et al., (2018) incorporated oat, inulin, pea and wheat fibre into the yogurt and found out no such noticeable variation in the $\mathrm{pH}$ and acidity although Fernandez-Garcia et al., (1998) concluded that the oat fibre elevates the $\mathrm{pH}$ slightly. It may be due to the consumption of free amino acids produced by the activity of starter culture. Studies have suggested similar kind of behaviour of the yogurt with the addition of inulin and carrot fibres as they were not able to alter the $\mathrm{pH}$ and acidity within the range of 2-6\%butwhole carrot particles in the range of $0.5 \%-2.0 \%$ boosts the fermentation and reduces the time required for the fermentation almost by one hour. Period of storage did not impact the difference between the $\mathrm{pH}$ of plain yogurt and fibre fortified yogurt. The bacterial count is also important in production of acids and fibres did not affect the bacterial count of end product. Apart from it pineapple pomace fibres reduced the time required to attain the desired $\mathrm{pH}$ and acidity by increasing the availability of nutrients required for growth of starter culture (Venica et al., 2020).

\section{Effect on the syneresis}

The syneresis of the yogurt is highly dependent on the water holding capacity of the constituents present in the yogurt. General phenomenon of relation between syneresis and fiber addition is that fibers have high water binding capacity which helps to reduce the syneresis percentage by holding the free water released by the gel structure. Dietary fibers can act as a stabilizer in the yogurt by retarding the movement of the free water in the structure. Some researchers also told the reasons behind it that dietary fibers have potential to interact through bridges of hydrogen with charges moieties on the protein surface. Although, the $\mathrm{pH}$ and storage time of yogurt also has an effect on the degree of syneresis. The syneresis formation is significantly lowered by the addition of carrot fiber (Venica et al., 2020), pea fibers, wheat fiber (Dabija et al., 2018), pineapple pomace powder (Sah et al., 2016) and pumpkin fiber (Bakirci et al., 2016) at the concentration around 1-1.5\%. High composition of soluble dietary fibre and their excellent water binding capacity is the reason behind the lower syneresis production. Pea fibres have reduced the syneresis percentage drastically and improved the viscosity more compared to wheat fibers as wheat fiber have high syneresis percentage at $1.5 \%$ concentration (Dabija et al., 2018).

\section{Effect on the rheological property}

Rheological properties considered important in processing of yogurt as it is thick product with characteristic gel structure. Viscosity of the yogurt is highly dependent upon the total solids present in the milk and syneresis produced after the fermentation. The variation in the viscosity is also contributed by the heat treatment given to the milk before the fermentation as it has impact on the level of denaturation of the proteins present in the milk. Fibres can act as filler between the yogurt components as dairy proteins interacts with exogenous hydrocolloids. Therefore, the viscosity and other rheological properties can improve after the addition of fibres into the yogurt (Dabija et al., 2018). Yogurts after the addition of fibres show non-Newtonian 
behaviour. Wheat fibre addition in the range of $1-1.5 \%$, oat fibre at $2-2.5 \%$ concentration and inulin at the level of $2-4 \%$ gives best viscous and firmness property to the yogurt due to interaction within the components. Apart from it, pineapple pomace fibre lowers the apparent viscosity of the yogurt may be due to the formation of weak network in the yogurt gel (Sah et al., 2016). The values of apparent viscosity, elastic modulus and viscous modulus increases as the percentage of different fibres increased (Bakirci et al., 2016).

\section{Effect on the sensory}

Quality evaluation of any product is highly affected by the sensory values as it is the most important and primary factor that affects the consumer perception. Fiber addition may take part in the improvement of the palatability, texture or other properties but the overall flavor has been the problem to overcome with fortification. Acetaldehyde production is hampered by the incorporation of fibers (Fernandez-Garcia et al., 1998). The flavor can be retained or improved by the use of essence of different fruits. Gritty or grainy like structure resulted from the addition of different fiber because of large particle size is also considered defect in the yogurt. It is essential to maintain the size of the fiber particle at minimum to achieve the greater sensory score. Fiber incorporation might be the reason behind less creaminess of the yogurt. The fortification of $2 \%$ wheat fiber and $2.5 \%$ pea fiber gives high overall acceptance values (Dabija et al., 2018). Hashim et al., (2009) also experimented with date fiber addition and noticed similar sensory properties between the plain yogurt and date fiber based yogurt at 3\% concentration. Oat fiber concentration of $1.32 \%$ defiantly improves the firmness and texture but also responsible for the reduction in the flavor. The color parameter is dependent on the type of fiber and the color of its source. The addition of date fiber resulted into more reddish colored yogurt while, yellowish or greenish colored yogurt resulted by the asparagus fiber addition. The higher grittiness is observed with the incorporation of carrot fiber and it is due to insolubility of carrot fiber (Venica et al., 2020).

\section{Supplementation with Minerals}

Every organism on earth requires minerals in the diet for their proper growth and functioning. At least 49 minerals are required in the human nutrition, out of 49, 23 minerals are required for biochemical and physiological activities. Compared to other nutrients like carbohydrates, proteins and lipids the need of minerals is less but they are must needed in the body for well-functioning. Some of the macro-minerals required in human nutrition are: calcium, chlorine, magnesium, phosphorus, potassium, sodium, iron and sulphur (Quintaes and Diez-Garcia, 2015).

Lesser consumption of minerals like calcium, iron and zinc than daily requirement might be an opening for several deficiencies like stunted growth in child, weakness in bones and immune system disorder. Yogurt is enriched with several nutrients like calcium, phosphorus and magnesium and deficient in minerals like iron and zinc. Yogurt has potential to increase its mineral composition by the fortification practice. In recent years many researches are conducted in the field of minerals fortified yogurt by fortifying nano and micro sized calcium, iron, zinc (SantillanUrquizaa et al., 2017; Singh and Muthukumarappan, 2008; Hekmat and Mcmahon, 1997; Nkhata, 2013), magnesium, manganese, molybdenum, chromium, selenium (Achanta et al., 2007) and iron entrapped niosomes (Gutierrez et al., 2016). It is clear that minerals can chemically interact with the yogurt components and have effect on the different properties of the yogurt as shown in 
Table.

Effect of minerals fortification on the $\mathrm{pH}$ and acidity of the yogurt

The acidity and $\mathrm{pH}$ of the yogurt is contributed by hydrolysis of lactose present in the milk by lactic acid bacteria. The mineral fortification does not affect the $\mathrm{pH}$ and acidity of yogurt. In comparison to plain yogurt, fortified yogurt has similar behavior regarding $\mathrm{pH}$ and acidity.

The $\mathrm{pH}$ decreases as acidity increases of the yogurt during the storage time (SantillanUrquizaa et al., 2017). Singh and Muthukumarappan, (2008) also found the similar results by fortifying calcium in fruit yogurt. The decrease in the $\mathrm{pH}$ during the storage period it's only due to accumulation of lactic acid by the activity of starter culture (Nkhata, 2013).

\section{Effect on the syneresis}

Syneresis is a phase separation naturally happens in the yogurt where gel structure of yogurt loses the water and it is dependent on many factors like total solids of milk, protein content, $\mathrm{pH}$ and acidity, time and temperature of storage. Syneresis production naturally happens in the yogurt but by perception of consumers it does affect the visual appearance of the yogurt. Effect of minerals fortification on the syneresis is mostly dependent on the size of the mineral particles i.e. micro and nono particles. Highest degree of syneresis is observed in the micro sized mineral fortified yogurt in comparison to nano particles fortified yogurt as it is more stable.

Increase in the storage time elevates the syneresis production in the mineral fortified yogurt generally because of casein rearrangement due to lower $\mathrm{pH}$ and releases the water. Minerals like iron, selenium and magnesium has good water holding capacity and resulted into low values of the syneresis. Lower level of minerals and shortest time of supplementation has positive impact on the water holding capacity to reduce the syneresis (Achanta et al., 2007).

\section{Effect on the rheological property}

The flow behavior of the yogurt is considered as rheological property of the yogurt. The supplementation with the minerals does not able to change the plastic behavior of the yogurt, but regarding apparent viscosity the deferent minerals can affect it differently.

Apparent viscosity of the yogurt supplemented with selenium, zinc and manganese is greater than the yogurt supplemented with chromium and magnesium. The lower viscosity of the chromium and magnesium fortified yogurt may be due to formation of more open structure including large void space between it.

In comparison to plain yogurt the change is not much in the minerals fortified yogurt especially with iron (Achanta et al., 2007). The yogurt fortified with calcium has more ability to retain its apparent viscosity in storage compared to plain yogurt (Singh and Muthukumarappan, 2008).

The size of the particle of minerals contributed most in altering the rheological property of yogurt. Consistency coefficient of the yogurt is increases when nano sized minerals are added. This may be because of greater interaction between the mineral compounds to casein micelles. The phenomenon is highly observed for mineral zinc. The supplementation of iron is not able to affect the consistency much due to lack of interaction between them. The decrease in the consistency during storage is the result of loosening of gel structure and mineral incorporation is not able to impact on it 
Int.J.Curr.Microbiol.App.Sci (2021) 10(04): 19-38

(Santillan-Urquizaa et al., 2017). 
Table.1 Supplementation of yogurt with different carbohydrates

\begin{tabular}{|c|c|c|c|c|c|c|c|c|c|c|}
\hline $\begin{array}{l}\text { Sr. } \\
\text { No. }\end{array}$ & $\begin{array}{l}\text { Type of } \\
\text { carbohydrate }\end{array}$ & $\begin{array}{c}\% \\
\text { added }\end{array}$ & pH & $\begin{array}{l}\text { Fermentation } \\
\text { Temperature }\end{array}$ & $\begin{array}{l}\text { Fat\% } \\
\text { of } \\
\text { milk }\end{array}$ & $\begin{array}{l}\text { SNF\% } \\
\text { of milk }\end{array}$ & Culture used & Viscosity & Syneresis \% & Reference \\
\hline 1. & $\begin{array}{l}\text { Sucrose/ Fructose/ } \\
\text { Lactose+ Sucrose }\end{array}$ & $\begin{array}{l}1.6- \\
2.0\end{array}$ & $\begin{array}{l}4.27- \\
4.29\end{array}$ & $42^{\circ} \mathrm{C}$ & 1.0 & 12.0 & - & $\begin{array}{l}79,334- \\
86,426 \\
\text { cps }\end{array}$ & - & $\begin{array}{l}\text { (Fernandez- } \\
\text { Garcia et al., } \\
\text { 1998) }\end{array}$ \\
\hline 2. & $\begin{array}{c}\text { Modified Cassava } \\
\text { Starch+ Sweet } \\
\text { Whey }\end{array}$ & $\begin{array}{l}1.2+ \\
45.0\end{array}$ & 3.90 & $42^{\circ} \mathrm{C}$ & 2.8 & 12.0 & $\begin{array}{c}\text { S. thermophilus, } \\
\text { Lb. bulgaricus and Lb. lactis }\end{array}$ & $\begin{array}{l}389.80 \pm \\
8.5 \mathrm{cP}\end{array}$ & $9.0 \pm 0.36$ & $\begin{array}{l}\text { (Imbachi- } \\
\text { Narvaez et al., } \\
\text { 2018) }\end{array}$ \\
\hline 3. & $\begin{array}{l}\text { Potato Starch/ } \\
\text { Maize Starch/ } \\
\text { Waxy Maize } \\
\text { Starch/ Tapioca } \\
\text { Starch }\end{array}$ & 1.5 & 4.7 & $44^{\circ} \mathrm{C}$ & 0.2 & - & $\begin{array}{l}\text { Lb. delbrueckii subsp. } \\
\text { Bulgaricus, Lb. delbrueckii } \\
\text { subsp. Lactis, } S . \\
\text { thermophilus }\end{array}$ & $\begin{array}{l}8,94 \pm 0,99 \\
-12,58 \pm \\
1,99 \mathrm{~Pa} . \mathrm{s}\end{array}$ & - & $\begin{array}{l}\text { (Najgebauer- } \\
\text { Lejko et al., } \\
\text { 2007) }\end{array}$ \\
\hline 4. & $\begin{array}{c}\text { Modified Tapioca } \\
\text { Starch/ } \\
\text { Chemically } \\
\text { Modified Maize } \\
\text { Starch/ Native } \\
\text { Maize Starch }\end{array}$ & 1.0 & - & $45 \pm 1^{\circ} \mathrm{C}$ & 1.25 & 12 & $\begin{array}{c}\text { Streptococcus thermophilus, } \\
\text { Lactobacillus bulgaricus } \\
\text { and Lactobacillus lactis }\end{array}$ & - & $2.5-7.4$ & $\begin{array}{l}\text { (Lobato- } \\
\text { Calleros et al., } \\
\text { 2014) }\end{array}$ \\
\hline 5. & Caramel Jam & $\begin{array}{c}10.0- \\
15.0\end{array}$ & $\begin{array}{l}4.88- \\
4.95\end{array}$ & $37^{\circ} \mathrm{C}$ & 0.2 & - & - & - & - & $\begin{array}{l}\text { (Ramirez- } \\
\text { Sucre and } \\
\text { Velez-Ruiz, } \\
\text { 2013) }\end{array}$ \\
\hline 6. & $\begin{array}{l}\text { Monk Fruit } \\
\text { Extract }\end{array}$ & 0.1 & $\begin{array}{c}4.37 \pm \\
0.21\end{array}$ & $41^{\circ} \mathrm{C}$ & - & - & $0.03 \%$ of $A B Y-8$ & $\begin{array}{l}4,331.86 \pm \\
199.57 \mathrm{~Pa}\end{array}$ & 17 & \multirow{2}{*}{$\begin{array}{l}\text { (Ban et al., } \\
\text { 2020) }\end{array}$} \\
\hline 7. & $\begin{array}{c}\text { Monk Fruit } \\
\text { Extract+ Sucrose }\end{array}$ & $\begin{array}{l}0.1+ \\
0.35\end{array}$ & $\begin{array}{c}4.41 \pm \\
0.12\end{array}$ & $41^{\circ} \mathrm{C}$ & - & - & $0.03 \%$ of $A B Y-8$ & $\begin{array}{l}4,286.86 \pm \\
199.57 \mathrm{~Pa}\end{array}$ & 15 & \\
\hline 8. & $\begin{array}{l}\text { Canna Edulis Ker } \\
\text { Starch/ Carboxy } \\
\text { Methyl Cellulose }\end{array}$ & $\begin{array}{c}0.1- \\
0.2\end{array}$ & 4.6 & $37^{\circ} \mathrm{C}$ & - & - & $\begin{array}{c}2 \% \text { of } 1: 1 \text { ratio of } S . \\
\text { Thermophilus \& } L . \\
\text { Bulgaricus }\end{array}$ & $\begin{array}{l}81.68- \\
84.83 \mathrm{cP}\end{array}$ & $\begin{array}{l}31.25 \pm 0.87- \\
32.94 \pm 0.58\end{array}$ & $\begin{array}{l}\text { (Umam et al., } \\
\text { 2018) }\end{array}$ \\
\hline 9. & Gaur Gum & 0.2 & 4.7 & $40^{\circ} \mathrm{C}$ & 1.7 & 8.5 & $\begin{array}{c}\text { S. thermophilus, } \\
\text { Lb.delbrukiisubsp. } \\
\text { bulgaricus, Lb. acidophilus, } \\
\text { Bifidobacterium lactis }\end{array}$ & - & - & $\begin{array}{l}\text { (Hussain et } \\
\text { al., 2017) }\end{array}$ \\
\hline
\end{tabular}


Table.2 Supplementation of yogurt with different minerals

\begin{tabular}{|c|c|c|c|c|c|c|c|c|c|c|c|}
\hline $\begin{array}{l}\text { Sr. } \\
\text { No }\end{array}$ & $\begin{array}{l}\text { Type of } \\
\text { mineral }\end{array}$ & $\begin{array}{l}\text { Recommended } \\
\text { Daily Intake }\end{array}$ & $\begin{array}{c}\text { Added \% of } \\
\text { Recommended } \\
\text { Daily Intake }\end{array}$ & Amount & $\mathbf{p H}$ & $\begin{array}{c}\text { Total } \\
\text { solids } \\
(\%)\end{array}$ & $\begin{array}{c}\text { Acidity } \\
(\%)\end{array}$ & $\begin{array}{c}\text { Syneresis } \\
(\%)\end{array}$ & Density & $\begin{array}{l}\text { Apparent } \\
\text { Viscosity } \\
\text { (cp) }\end{array}$ & Reference \\
\hline 1. & $\begin{array}{c}\mathrm{Ca} \\
\text { (nano) }\end{array}$ & $800 \mathrm{mg}$ & $30 \%$ & $240 \mathrm{mg}$ & $4.65 \pm 0.01$ & 17.98 & $\begin{array}{c}0.87 \pm \\
0.01\end{array}$ & $42.10 \pm 0.01$ & $\begin{array}{c}1045.32 \pm \\
0.52\end{array}$ & - & \multirow{4}{*}{$\begin{array}{l}\text { (Santillán- } \\
\text { Urquiza et } \\
\text { al., 2017) }\end{array}$} \\
\hline 2. & $\begin{array}{c}\mathrm{Ca} \\
\text { (micro) }\end{array}$ & $800 \mathrm{mg}$ & $30 \%$ & $240 \mathrm{mg}$ & $4.62 \pm 0.01$ & 17.76 & $\begin{array}{c}0.86 \pm \\
0.01\end{array}$ & $46.52 \pm 0.01$ & $\begin{array}{c}1047.84 \pm \\
0.32\end{array}$ & - & \\
\hline 3. & $\begin{array}{c}\mathrm{Zn} \\
\text { (nano) }\end{array}$ & $15 \mathrm{mg}$ & $50 \%$ & $7.5 \mathrm{mg}$ & $\begin{array}{c}4.77 \pm \\
0.01\end{array}$ & 17.41 & $\begin{array}{c}0.86 \pm \\
0.01\end{array}$ & $\begin{array}{c}48.48 \pm \\
0.01\end{array}$ & $\begin{array}{c}1049.44 \pm \\
0.70\end{array}$ & - & \\
\hline 4. & $\begin{array}{c}\mathrm{Zn} \\
\text { (micro) }\end{array}$ & $15 \mathrm{mg}$ & $50 \%$ & $7.5 \mathrm{mg}$ & $\begin{array}{c}4.71 \pm \\
0.01\end{array}$ & 17.04 & $\begin{array}{c}0.86 \pm \\
0.01\end{array}$ & $\begin{array}{c}51.18 \pm \\
0.01\end{array}$ & $\begin{array}{c}1045.24 \pm \\
0.47\end{array}$ & - & \\
\hline 3. & $\mathrm{Fe}$ & $15 \mathrm{mg}$ & $25 \%$ & $3.75 \mathrm{mg}$ & - & - & - & $\begin{array}{c}31.11 \pm \\
5.57\end{array}$ & - & $\begin{array}{c}15,406.47 \pm \\
1,349.39\end{array}$ & \multirow{2}{*}{$\begin{array}{l}\text { (Achanta } e t \\
\text { al., 2007) }\end{array}$} \\
\hline 4. & $\mathrm{Mg}$ & $420 \mathrm{mg}$ & $25 \%$ & $105 \mathrm{mg}$ & - & - & - & $\begin{array}{c}35.00 \pm \\
1.67\end{array}$ & - & $\begin{array}{c}13,747.69 \pm \\
513.24\end{array}$ & \\
\hline 7. & $\mathrm{Zn}$ & $15 \mathrm{mg}$ & $25 \%$ & $3.75 \mathrm{mg}$ & - & - & - & $\begin{array}{c}37.78 \pm \\
3.09\end{array}$ & - & $\begin{array}{c}16,654.57 \pm \\
837.42\end{array}$ & \multirow{3}{*}{$\begin{array}{r}\text { (Achanta } e \\
\text { al., 2007) }\end{array}$} \\
\hline 8. & $\mathrm{Mn}$ & $5 \mathrm{mg}$ & $25 \%$ & $1.25 \mathrm{mg}$ & - & - & - & $\begin{array}{c}34.44 \pm \\
4.07\end{array}$ & - & $\begin{array}{c}16,745.45 \pm \\
969.35\end{array}$ & \\
\hline 9. & Mo & $200 \mu \mathrm{g}$ & $25 \%$ & $50 \mu \mathrm{g}$ & - & - & - & $\begin{array}{c}35.00 \pm \\
1.67\end{array}$ & - & $\begin{array}{c}15,377.18 \pm \\
1,242.70\end{array}$ & \\
\hline 10. & $\begin{array}{l}\mathrm{Fe}+\mathrm{Zn} \\
\text { (nano) }\end{array}$ & $15+15 \mathrm{mg}$ & $50 \%+80 \%$ & $\begin{array}{c}7.5+12 \\
\mathrm{mg}\end{array}$ & $\begin{array}{c}4.77 \pm \\
0.01\end{array}$ & 16.50 & $\begin{array}{c}0.87 \pm \\
0.01\end{array}$ & $\begin{array}{c}43.00 \pm \\
0.01\end{array}$ & $\begin{array}{c}1049.78 \pm \\
0.99\end{array}$ & - & \multirow{2}{*}{$\begin{array}{l}\text { (Santillán- } \\
\text { Urquiza et } \\
\text { al., 2017) }\end{array}$} \\
\hline 11. & $\begin{array}{l}\mathrm{Fe}+\mathrm{Zn} \\
\text { (micro) }\end{array}$ & $15+15 \mathrm{mg}$ & $50 \%+80 \%$ & $\begin{array}{c}7.5+12 \\
\mathrm{mg}\end{array}$ & $\begin{array}{c}4.71 \pm \\
0.01\end{array}$ & 16.24 & $\begin{array}{c}0.86 \pm \\
0.01\end{array}$ & $\begin{array}{c}55.39 \pm \\
0.01\end{array}$ & $\begin{array}{c}1051.33 \pm \\
0.92\end{array}$ & - & \\
\hline 12. & $\mathrm{Cr}$ & $200 \mu \mathrm{g}$ & $25 \%$ & $50 \mu \mathrm{g}$ & - & - & - & $\begin{array}{c}34.44 \pm \\
5.57\end{array}$ & - & $\begin{array}{c}14,141.62 \pm \\
354.04\end{array}$ & \multirow{2}{*}{$\begin{array}{r}\text { (Achanta } e \\
\text { al., 2007) }\end{array}$} \\
\hline 13. & $\mathrm{Se}$ & $70 \mu \mathrm{g}$ & $25 \%$ & $17.5 \mu \mathrm{g}$ & - & - & - & $\begin{array}{c}35.00 \pm \\
1.67\end{array}$ & - & $\begin{array}{c}16,597.08 \pm \\
1,074.16\end{array}$ & \\
\hline
\end{tabular}


Iron entrapped niosomes supplemented yogurt resulted into increase in the firmness of the product compared to plain and non-entrapped iron fortified yogurt (Gutierrez et al., 2016).

\section{Effect on the sensory}

Sensory property of the yogurt is majorly depends upon the solubility of the minerals. Nano particles of minerals are more soluble in the yogurt than micro particles. Nano particles have tendency to interact more efficiently than micro particles of same mineral. The supplementation of minerals can be achieved without much interferes in the sensory properties of yogurt. Santillan-Urquizaa et al., (2017) and Singh and Muthukumarappan, (2008) reported no significant changes in the sensory properties with incorporating different minerals. There is no evidence on impact of minerals on acetaldehyde production during fermentation process of yogurt as acetaldehyde is a prime source of characteristic flavour of yogurt. Minerals can have slight effect on the colour of final yogurt as lightness values of the chromium, magnesium, manganese and molybdenum fortified yogurt increases in comparison with plain yogurt because of changes in structure of dairy proteins. Different minerals have no tendency to alter the body, texture and appearance of the yogurt (Achanta et al., 2007). Iron can have defective effect on the flavor as it gives metallic flavor to the yogurt but it is highly dependent on the source of the iron (Hekmat and Mcmahon, 1997).

\section{Supplementation with vitamins}

Vitamins are essential for the normal functioning and metabolism and are made up of very complex compounds which are organic in nature and deficiencies of them cause serious disorders to human body. The deficiency of the vitamins can be cured by the supplementation of vitamins. Vitamins are essential for development, growth, maintenance and lack of vitamins cause adverse effect to the health. Total of 13 vitamins considered as true and subdivided into water soluble and fat soluble vitamins. Fat soluble vitamins are vitamin $\mathrm{A}, \mathrm{K}, \mathrm{D}$ and $\mathrm{E}$ whereas, water soluble vitamins are vitamin $\mathrm{C}$, B1, B2, B3, B5, B6, B9, B12 and biotic. Vitamins are available in both plant and animal sources in trace amounts (Maqbool et al., 2018). Very few studies have been conducted till date on supplementation of yogurt with vitamins like thiamine (vitamin B1), riboflavin (vitamin B2), niacin (vitamin B3), folic acid (vitamin B9) (Cueva and Aryana, 2008), vitamins, vitamin C (Ilic and Ashoor, 1998), nano-liposomal Vitamin D (Jafari et al., 2019), lipophilic vitamins like vitamin A, D and E (Ozturk, 2017), Betacarotene (Molina et al., 2018), B-complex Vitamins (Reddy et al., 1976). Vitamins are highly bioactive compounds and to retain them in processing and storage is very difficult in yogurt.

\section{Effect of supplementation of vitamins on pH and acidity of yogurt}

Acidity and $\mathrm{pH}$ of yogurt is generally dependent on lot of factors like initial bacterial count, quality of bacterial strain, properties of milk and incubation temperature. Incorporation of such vitamins certainly lowers the $\mathrm{pH}$ and increases the acidity of the yogurt but comparing different minerals there is no such noticeable different in $\mathrm{pH}$ amongst themselves. Regarding the storage days the $\mathrm{pH}$ decreases as the lactose is continuously fermented to lactic acid by the lactic acid bacteria (Cueva and Aryana, 2008). Although, some scientists found no significant difference in the $\mathrm{pH}$ and acidity of yogurt by fortifying it with vitamins like vitamin $\mathrm{A}$ and $\mathrm{C}$. Ilic and Ashoor, (1998) observed no effect of vitamin $\mathrm{A}$ and $\mathrm{C}$ on the $\mathrm{pH}$, acidity and fermentation time. Acidic nature of yogurt helps to retain 
the vitamin $\mathrm{C}$ as it is stable at low pH (Ilic and Ashoor, 1998).

\section{Effect on syneresis}

Syneresis of yogurt generally detects the water released by the gel structure of yogurt during the fermentation and storage. Syneresis is dependent on the total solids present in the milk and water holding capacity of solids. Vitamin incorporation into the yogurt is generally not affect the amount of syneresis produced after the processing and in the storage. The particle size of selected vitamins play major role in the syneresis production (Cueva and Aryana, 2008). There are very few researches are available regarding the effect of vitamins supplementation on syneresis of yogurt hence, it is very difficult to conclude anything confidently.

\section{Effect on viscosity}

The viscosity of the yogurt majorly dependent on the syneresis produced during fermentation and the percentage of total solids. Vitamins concentration to be supplemented in the yogurt can affect the rheological property of yogurt. Addition of $60 \%$ of vitamins of their recommended daily intake increases the viscosity of the yogurt. The increase in the viscosity of yogurt may be due to increased solids and their water holding capacity (Cueva and Aryana, 2008).

\section{Effect on sensory}

Sensory evaluation of the yogurt dictates the consumer perception towards it. There is no significant change is observed regarding the sensory characteristics like flavor, body texture and appearance of the yogurt supplemented with vitamins. The concentration should be added in the yogurt to achieve the daily intake of vitamins is not enough to alter such sensory properties of the yogurt. The addition of vitamins can have impact on the color of the yogurt as is may give greenish appearance but it can only be detected by the machines(Cueva and Aryana, 2008). Vitamin $C$ addition may give the final yogurt a tinge of yellowness. The colour change in the yogurt dependant on the source of the vitamins incorporated. The same result regarding flavour, appearance, taste and body texture was confirmed by Ilic and Ashoor, (1998). Vitamins not able to interact with acetaldehyde production during fermentation of yogurt and subsequently doesn't change the acidic flavour of yogurt (Ilic and Ashoor, 1998). Many researchers focused on the production of fortified yogurt with the incorporation of natural ingredients.

Supplementation of natural food components can increase the nutritional profile of the yogurt with minimum adverse effects. The components of fortifying agents can have a chemical interaction with the active compounds present in the yogurt. Incorporation can contribute to a change in the rheological properties, syneresis, $\mathrm{pH}$, acidity, bacterial count and sensory attributes of yogurt.

The production of fortified yogurt without altering the sensory attributes still a challenge. Additional flavouring agents can be used to mask the flavour change due the fortifying agent. Addition of vital vitamins and minerals to produce healthy yogurt still have a scope in dairy sector. Fortified yogurt can cover the malnutrition and deficiency of vital nutrients in the diet of peoples in developing and underdeveloped countries. Functional food from milk and milk products can be produced to cure many diseases. This review covered the effect of different food components on physicochemical as well as sensory characteristics of yogurt with increasing the nutritional profile. 


\section{References}

Achanta, K., Aryana, K. J., \& Boeneke, C. A. (2007). Fat free plain set yogurts fortified with various minerals. LWTFood Science and Technology, 40(3), 424-429.

Akalın, A. S., Unal, G., Dinkci, N. A. Y. İ. L., \& Hayaloglu, A. A. (2012). Microstructural, textural, and sensory characteristics of probiotic yogurts fortified with sodium calcium caseinate or whey protein concentrate. Journal of Dairy Science, 95(7), 36173628.

Amaya-Llano, S. L., Martínez-Alegría, A. L., Zazueta-Morales, J. J., \& MartínezBustos, F. (2008). Acid thinned jicama and maize starches as fat substitute in stirred yogurt. LWT-Food Science and Technology, 41(7), 1274-1281.

Astrup, A. (2014). Yogurt and dairy product consumption to prevent cardiometabolic diseases: epidemiologic and experimental studies. The American journal of clinical nutrition, 99(5), 1235S-1242S.

Bakirci, S., Dagdemir, E., Boran, O. S., \&Hayaloglu, A. A. (2017). The effect of pumpkin fibre on quality and storage stability of reduced-fat set- type yogurt. International Journal of Food Science \& Technology, 52(1), 180-187.

Ban, Q., Liu, Z., Yu, C., Sun, X., Jiang, Y., Cheng, J., \& Guo, M. (2020). Physiochemical, rheological, microstructural, and antioxidant properties of yogurt using monk fruit extract as a sweetener. Journal of Dairy Science.

Chandan, R. C., Gandhi, A., \& Shah, N. P. (2017). Yogurt: Historical background, health benefits, and global trade. In Yogurt in health and disease prevention (pp. 3-29). Academic Press.
Cueva, O., \& Aryana, K. J. (2008). Quality attributes of a heart healthy yogurt. LWT-Food Science and Technology, 41(3), 537-544.

Dabija, A., Codină, G. G., Gâtlan, A. M., \& Rusu, L. (2018). Quality assessment of yogurt enriched with different types of fibers. CyTA-Journal of Food, 16(1), 859-867.

Damin, M. R., Alcântara, M. R., Nunes, A. P., \& Oliveira, M. N. (2009). Effects of milk supplementation with skim milk powder, whey protein concentrate and sodium caseinate on acidification kinetics, rheological properties and structure of nonfat stirred yogurt. LWT-Food Science and Technology, 42(10), 1744-1750.

Dave, R. I., \& Shah, N. P. (1998). The influence of ingredient supplementation on the textural characteristics of yogurt. Australian Journal of Dairy Technology, 53(3), 180.

Dhingra, D., Michael, M., Rajput, H., \& Patil, R. T. (2012). Dietary fibre in foods: a review. Journal of food science and technology, 49(3), 255-266.

Drake, M. A., Chen, X. Q., Tamarapu, S., \& Leenanon, B. (2000). Soy protein fortification affects sensory, chemical, and microbiological properties of dairy yogurts. Journal of Food Science, 65(7), 1244-1247.

Fernández-Garía, E., McGregor, J. U., \& Traylor, S. (1998). The addition of oat fiber and natural alternative sweeteners in the manufacture of plain yogurt. Journal of dairy science, 81(3), 655663.

Gahruie, H. H., Eskandari, M. H., Mesbahi, G., \& Hanifpour, M. A. (2015). Scientific and technical aspects of yogurt fortification: A review. Food Science and Human Wellness, 4(1), 18. 
Gupta, C., Chawla, P., Arora, S., Tomar, S. K., \& Singh, A. K. (2015). Iron microencapsulation with blend of gum arabic, maltodextrin and modified starch using modified solvent evaporation method-milk fortification. Food Hydrocolloids, 43, 622-628.

Gutiérrez, G., Matos, M., Barrero, P., Pando, D., Iglesias, O., \& Pazos, C. (2016). Iron-entrapped niosomes and their potential application for yogurt fortification. $L W T, 74,550-556$.

Haque, Z. Z., \& Aryana, K. J. (2002). Effect of sweeteners on the microstructure of yogurt. Food Science and Technology Research, 8(1), 21-23.

Hashim, I. B., Khalil, A. H., \& Afifi, H. S. (2009). Quality characteristics and consumer acceptance of yogurt fortified with date fiber. Journal of dairy science, 92(11), 5403-5407.

Hekmat, S., \& Mcmahon, D. J. (1997). Manufacture and quality of ironfortified yogurt. Journal of dairy science, 80(12), 3114-3122.

Hoppert, K., Zahn, S., Jänecke, L., Mai, R., Hoffmann, S., \& Rohm, H. (2013). Consumer acceptance of regular and reduced-sugar yogurt enriched with different types of dietary fiber. International Dairy Journal, 28(1), 17.

Hossain, M. K., Keidel, J., Hensel, O., \& Diakité, M. (2020). The impact of extruded microparticulated whey proteins in reduced-fat, plain-type stirred yogurt: Characterization of physicochemical and sensory properties. $L W T, 134,109976$.

Ilic, D. B., \& Ashoor, S. H. (1988). Stability of vitamins $\mathrm{A}$ and $\mathrm{C}$ in fortified yogurt. Journal of dairy science, 71(6), 14921498.

Imbachí-Narváez, P. C., Sepúlveda-Valencia, J. U., \& Rodriguez-Sandoval, E. (2019). Effect of modified cassava starch on the rheological and quality properties of a dairy beverage prepared with sweet whey. Food Science and Technology, 39(1), 134-142.

Isleten, M., \& Karagul- Yuceer, Y. O. N. C. A. (2008).Effects of functional dairy based proteins on nonfat yogurt quality. Journal of food quality, 31(3), 265-280.

Jafari, S. M., Vakili, S., \& Dehnad, D. (2019). Production of a functional yogurt powder fortified with nanoliposomal vitamin D through spray drying. Food and Bioprocess Technology, 12(7), 1220-1231.

Jovanović, M., Petrović, M., Miočinović, J., Zlatanović, S., LaličićPetronijević, J., Mitić-Ćulafić, D., \& Gorjanović, S. (2020). Bioactivity and Sensory Properties of Probiotic Yogurt Fortified with Apple Pomace Flour. Foods, 9(6), 763.

Karam, M. C., Gaiani, C., Hosri, C., Burgain, J., \&Scher, J. (2013). Effect of dairy powders fortification on yogurt textural and sensorial properties: a review. The Journal of dairy research, 80(4), 400.

Kieserling, K., Vu, T. M., Drusch, S., \& Schalow, S. (2019). Impact of pectinrich orange fibre on gel characteristics and sensory properties in lactic acid fermented yoghurt. Food Hydrocolloids, 94, 152-163.

Kök, M. S. (2010). Characterization of galactomannan stabilised yogurt drink using dynamic rheology. International Journal of Food Properties, 13(1), 209-220.

Kristo, E., Biliaderis, C. G., \&Tzanetakis, N. (2003). Modelling of the acidification process and rheological properties of milk fermented with a yogurt starter culture using response surface methodology. Food Chemistry, 83(3), 437-446. 
Lee, W. J., \& Lucey, J. A. (2010). Formation and physical properties of yogurt. Asian-Australasian Journal of Animal Sciences, 23(9), 1127-1136.

Lobato-Calleros, C., Ramírez-Santiago, C., Vernon-Carter, E. J., \& AlvarezRamirez, J. (2014). Impact of native and chemically modified starches addition as fat replacers in the viscoelasticity of reduced-fat stirred yogurt. Journal of Food Engineering, 131, 110-115.

Maqbool, M. A., Aslam, M., Akbar, W., \& Iqbal, Z. (2018). Biological importance of vitamins for human health: A review. Journal of Agriculture and Basic Science, 2.

Marafon, A. P., Sumi, A., Granato, D., Alcântara, M. R., Tamime, A. Y., \& de Oliveira, M. N. (2011). Effects of partially replacing skimmed milk powder with dairy ingredients on rheology, sensory profiling, and microstructure of probiotic stirred-type yogurt during cold storage. Journal of Dairy Science, 94(11), 5330-5340.

Marette, A., Pickard-Deland, E., 2014. First global summit on the health benefits of yogurt: yogurt consumption and impact on health: focus on children and cardiometabolic risk. Am. J. Clin. Nutr.99, 1243S-1247S.

Mehar-Afroz, Q., Swaminathan, K., Karthikeyan, P., Pervez, K., \&Umesh, M. (2012). Application of nanotechnology in food and dairy processing: An overview. Pakistan Journal of Food Sciences, 22 (1), 2331.

Molina, C. V., Lima, J. G., Moraes, I. C., \& Pinho, S. C. (2019). Physicochemical characterization and sensory evaluation of yogurts incorporated with beta-carotene-loaded solid lipid microparticles stabilized with hydrolyzed soy protein isolate. Food science and biotechnology, 28(1), 5966.

Morell, P., Piqueras-Fiszman, B., Hernando, I., \& Fiszman, S. (2015). How is an ideal satiating yogurt described? A case study with added-protein yogurts. Food Research International, 78, 141147.

Najgebauer-Lejko, D., Sady, M., Grega, T., Faber, B., Domagała, J., \& Machaczka, B. (2007). Effect of addition of starches of different botanical origin on the texture and rheological properties of set-style yogurts. Biotechnology in Animal Husbandry, 23(5-6-2), 95-102.

Nestle, M. (2013). Food politics: How the food industry influences nutrition and health (Vol. 3). Univ of California Press.

O'connell, J. E., \& Fox, P. F. (2001). Significance and applications of phenolic compounds in the production and quality of milk and dairy products: a review. International Dairy Journal, 11(3), 103-120.

Ocak, E., \& Köse, Ș. (2010). The effects of fortifying milk with $\mathrm{Cu}, \mathrm{Fe}$ and $\mathrm{Zn}$ minerals on the production and texture of yoghurt. Journal of Food, Agriculture \& Environment, 8(2), 122125.

Öztürk, B. (2017). Nano emulsions for food fortification with lipophilic vitamins: Production challenges, stability, and bioavailability. European Journal of Lipid Science and Technology, 119(7), 1500539.

Peng, Y., Serra, M., Horne, D. S., \& Lucey, J. A. (2009). Effect of fortification with various types of milk proteins on the rheological properties and permeability of nonfat set yogurt. Journal of food science, 74(9), C666-C673.

Peng, Y., Serra, M., Horne, D. S., \& Lucey, J. A. (2009). Effect of fortification with 
various types of milk proteins on the rheological properties and permeability of nonfat set yogurt. Journal of food science, 74(9), C666-C673.

Quintaes, K. D., \& Diez- Garcia, R. W. (2015). The importance of minerals in the human diet. Handbook of Mineral Elements in Food, 1-21.

Ramirez-Santiago, C., Ramos-Solis, L., Lobato-Calleros, C., Peña-Valdivia, C., Vernon-Carter, E. J., \& AlvarezRamírez, J. (2010). Enrichment of stirred yogurt with soluble dietary fiber from Pachyrhizuserosus L. Urban: Effect on syneresis, microstructure and rheological properties. Journal of Food Engineering, 101(3), 229-235.

Ramírez-Sucre, M. O., \& Vélez-Ruiz, J. F. (2013). Physicochemical, rheological and stability characterization of a caramel flavored yogurt. LWT-Food Science and Technology, 51(1), 233241.

Reddy, K. P., Shahani, K. M., \&Kulkarni, S. M. (1976). B-complex vitamins in cultured and acidified yogurt. Journal of dairy science, 59(2), 191-195.

Repin, N., Scanlon, M. G., \&Fulcher, R. G. (2012). Phase behaviour of casein micelles and barley beta-glucan polymer molecules in dietary fibreenriched dairy systems. Journal of colloid and interface science, 377(1), 7-12.

Sabater, C., Abad-García, C., DelgadoFernández, P., Corzo, N., \& Montilla, A. (2020).Carbohydrate fraction characterisation of functional yogurts containing pectin and pectic oligosaccharides through convolutional networks. Journal of Food Composition and Analysis, 103484.

Sah, B. N. P., Vasiljevic, T., McKechnie, S., \& Donkor, O. N. (2016). Physicochemical, textural and rheological properties of probiotic yogurt fortified with fibre-rich pineapple peel powder during refrigerated storage. LWT-Food Science and Technology, 65, 978-986. Santillán-Urquiza, E., Méndez-Rojas, M. Á., \& Vélez-Ruiz, J. F. (2017). Fortification of yogurt with nano and micro sized calcium, iron and zinc, effect on the physicochemical and rheological properties. LWT, 80, 462469.

Schkoda, P., Hechler, A., \&Hinrichs, J. (2001). Influence of the protein content on structural characteristics of stirred fermented milk. Milchwissenschaft, 56(1), 19-22.

Sendra, E., Kuri, V., Fernández-López, J., Sayas-Barbera, E., Navarro, C., \& Pérez-Alvarez, J. A. (2010). Viscoelastic properties of orange fiber enriched yogurt as a function of fiber dose, size and thermal treatment. $L W T$ Food Science and Technology, 43(4), 708-714.

Séverin, S., \& Wenshui, X. (2005).Milk biologically active components as nutraceuticals. Critical reviews in food science and nutrition, 45(7-8), 645656.

Sharifi, A., Golestan, L., \& SharifzadehBaei, M. (2013).Studying the enrichment of ice cream with alginate nanoparticles including $\mathrm{Fe}$ and $\mathrm{Zn}$ salts. Journal of Nanoparticles, 2013.

Singh, G., \& Muthukumarappan, K. (2008). Influence of calcium fortification on sensory, physical and rheological characteristics of fruit yogurt. LWTFood Science and Technology, 41(7), 1145-1152.

Sodini, I., Montella, J., \& Tong, P. S. (2005). Physical properties of yogurt fortified with various commercial whey protein concentrates. Journal of the Science of Food and Agriculture, 85(5), 853-859.

Soukoulis, C., Panagiotidis, P., Koureli, R., \& 
Tzia, C. (2007). Industrial yogurt manufacture: monitoring of fermentation process and improvement of final product quality. Journal of dairy science, 90(6), 2641-2654.

Tamime, A. Y., \& Robinson, R. K. (1999). Yoghurt: science and technology. Wood head Publishing.

Tiţa, A., \&Tiţa, O. (2017). Influence of chia powder in low fat stirred yogurt. International Multidisciplinary Scientific Geo Conference: SGEM, 17, 761-768.

Tomic, N., Dojnov, B., Miocinovic, J., Tomasevic, I., Smigic, N., Djekic, I., \& Vujcic, Z. (2017). Enrichment of yoghurt with insoluble dietary fiber from triticale-A sensory perspective. LWT, 80, 59-66.

Umam, A. K., Lin, M. J., Radiati, L. E., \& Peng, S. Y. (2019). The Capability of Canna edulis Ker Starch as Carboxymethyl Cellulose Replacement on Yogurt Drink during Cold Storage. ANIMAL PRODUCTION, 20(2), 109118.

USDA (2002). Food consumption (per capita) data system. Economic Research Service.

Vénica, C. I., Spotti, M. J., Pavón, Y. L., Molli, J. S., \& Perotti, M. C. (2020). Influence of carrot fibre powder addition on rheological, microstructure and sensory characteristics of stirred- type yogurt. International Journal of Food Science \& Technology, 55(5), 1916-1923.

Yousef, A. E., \& Carlstrom, C. (2003). Food microbiology: a laboratory manual. John Wiley \& Sons.

Zare, F., Orsat, V., Champagne, C., Simpson, B. K., \& Boye, J. I. (2012). Microbial and physical properties of probiotic fermented milk supplemented with lentil flour. Journal of Food Research, l(1), 94.

\section{How to cite this article:}

Kumthekar, S. B., S. S. Temgire, A. B. Idate and Gaikwad, V. R. 2021. Effect of Supplementation on the Properties of Yogurt: A Review. Int.J.Curr.Microbiol.App.Sci. 10(04): 19-38. doi: https://doi.org/10.20546/ijcmas.2021.1004.003 